\title{
ENVIRONMENTAL INDICATORS LEADING TO \\ CARDIAC MALFUNCTION AMONG TEXTILE WORKERS
}

\author{
Ragab, M. H. ${ }^{(1)}$; Awadalla, Halla, I. $^{(1)}$; Attia, A. I. ${ }^{(2)}$ \\ and Emara, A. M. M. ${ }^{(3)}$ \\ 1) Institute of environmental studies and research, Ain Shams University \\ 2) Faculty of medicine, Benha University. 3) Mahala Cardiac Center, \\ Ministry of Health and population.
}

\begin{abstract}
Background: In the Registrar General's Decennial Supplement for 1951, bronchitis and myocardial degeneration were both responsible for excessive mortality among cotton spinners and chronic rheumatic disease was an important, although relatively rare, cause of death for cotton weavers.

Aim of the work: The present study designed to investigate the environmental indicators and risk factors in textile workers that increase risk of cardiac malfunction and personal conventional risk factors in textile workers that increase risk of cardiac malfunction. In addition, the most susceptible persons to cardiac malfunction among the exposed workers in textile job to avoid exposure as preventive measures.

Subjects and methods: A cross sectional study that included workers in textile companies mainly the most exposed persons to environmental and conventional risk factors. Subjects were divided into two groups: Group A: included subjects exposed to risk factors insides textile departments [included 120 subjects who fulfilled inclusion criteria]; Group B: included non-exposed subjects in the other departments, as a control group [included 120 subjects]. Inclusion criteria included the following: male subject, age more than 30 years, work period inside factor is more than 5 years and control group not exposed to textile risk factors before. All cases were underwent full history taking, clinical evaluation, laboratory evaluation and ECG examination.

Results: There was significant increase of known environmental risk factors(chemical and physical), past history of medical risk factors, smoking, blood pressure, heart rate, lipid profile and ECG abnormalities in study group,


when compared to control group. On the other hand, there was insignificant difference between cases and controls as regard age, marital state, BMI, random blood sugar, alcohol drinking or duration of work.

Conclusion: There is an association between environmental risk factors and development of cardio-vascular disease; and it can be explained by that: environmental risk especially noise and temperature variations leads to increased traditional risk factors of CVD and subsequently development of the disease.

Key words: air pollution, cardiovascular disease, textile industry

\section{INTRODUCTION}

Cotton is a soft fluffy staple fiber that grows in a boll, or protective capsule, around the seeds of cotton plants of the genus Gossypium. The plant is a shrub native to tropical and subtropical regions around the world, including the Americas, Africa, India, and Pakistan. The fiber most often is spun into yarn or thread and used to make a soft, breathable textile, which is the most widely, used natural-fiber cloth in clothing today. The English name derived from the Arabic [al] qutn, which began to be used circa 1400 [Metcalf, 1999]

In the Registrar General's Decennial Supplement for 1951, bronchitis and myocardial degeneration were both responsible for excessive mortality among cotton spinners and chronic rheumatic disease was an important, although relatively rare, cause of death for cotton weavers [Molyneux and Tombleson, 1970]. The well-recognized conventional risk factors such as: high cholesterol level, diabetes, hypertension, obesity, physical inactivity, unhealthy diet, genetic predisposition and active or passive tobacco smoking are responsible for only about 50\% cases of cardiovascular diseases [Kristensen, 1989]. 
There are reports on two hundred other factors, including chemical and physical hazards, factors dependent on the type of job and work organization as well as psychological and social ones that may be related to the cardiovascular diseases. Data have now become available for a further 10year period from 1991 to 2000, and we have used this new information to explore in more detail the risk of death from diabetes in garment and textile workers, and also from ischemic heart disease [IHD], which like diabetes is more common in immigrants from the Indian Sub-Continent [Harding et al., 2008].

\section{AIM OF THE WORK}

The present study was designed to investigate the environmental indicators and risk factors in textile workers that increase risk of cardiac malfunction and personal conventional risk factors in textile workers that increase risk of cardiac malfunction. In addition, to identify the most susceptible persons to cardiac malfunction among the exposed.

\section{MATERIALS AND METHODS}

A cross sectional study that included workers in textile companies mainly the most exposed persons to environmental and conventional risk factors. Subjects were divided into two groups: Group A: included subjects exposed to risk factors insides textile departments [included 120 subjects who fulfilled inclusion criteria]; Group B: included non-exposed subjects in the other departments, as a control group [included 120 subjects]. Inclusion criteria included the following: male subject, age more than 30 years, work period 
inside factor is more than 5 years and control group not exposed to textile risk factors before.

Work environment: the textile factory included three separate departments: pre-spinning, spinning, and weaving. Not all the workers wear masks because of inconvenience. In the prespinning or preparation stage, large bales containing packed cotton are manually opened within an enclosed space. The cotton is then fluffed and beaten with beater bars in order to loosen the material, and sifted in order to remove seeds and other impurities. Next, the cotton is fed through rollers until it becomes a continuous sheet. In carding, the fibers are separated and then brought together into a loose string [known as a "sliver']. Drawing is done to straighten and combine several slivers to be separated into "rovings" which are used in the spinning process. In the spinning department, the machines take the roving to be thinned and twisted, producing yarn which is wound into bobbins. This process is wet using water aerosols. The weaving process uses looms to produce fabrics.

Exposure definition: Each factory was assigned to an industry sector based on manufacturing materials and processes. The sectors were: [1] cotton spinning, weaving, and knitting [SWK]; [2] silk SWK; [3] wool SWK; [4] synthetic fiber SWK; [5] mixed fiber SWK; [6] garment assembly and sewing; [7] bleaching/dyeing/printing; [8] machine manufacturing; [9] combined; and [10] other services.

Sectors were designated as "combined" if the factory had multiple production lines that could be assigned with two or more sector codes. The sector of the factory workers reported at the time of enrollment [baseline] was 
used as a proxy for prior exposures. The "baseline factory" was defined as the current factory for active employees at the time of interview, and the last place worked for men who were retired at interview. The sectors were further classified with respect to exposures of interest for which other literature suggests associations with CVD risks. Working in one of the sectors known to have high dust levels [cotton, wool, synthetic, and mixed fiber SWK] was considered a proxy for exposure to particulate matter. Since endotoxin is a known contaminant of cotton dust, working in the cotton SWK sector was analyzed as a proxy for endotoxin exposure.

\section{METHODS}

The study was performed as the following: the work place and environmental risk factors that may lead to risky diseases were studied; and they included: chemical factors such as carbon monoxide, organic solvents, dyes and particulate dusts; physical factors such as noise, hot or cold microclimate, considerable temperature variation [due to shifting from one location to another], moisture, electromagnetic field [from $50 \mathrm{~Hz}$ high voltages or currents in power lines and associated equipments], general or local vibration.

Comparison between exposed and non-exposed groups was done according to personal history, past \& family history, occupational history (e.g., date of starting work inside company, duration of exposure, type of job); physical examination and laboratory investigations 
Electrocardiogram: was done to study the cardiac properties, which included: contractility, conductivity, automaticity and rhythmicity: a 12 lead ECG was recorded at paper speed of $25 \mathrm{~mm} / \mathrm{s}$ and amplification of $10 \mathrm{~mm} / \mathrm{mV}$, with full analysis of ECG data: [standardization, and technical quality, heart rate, rhythm, PR interval, P wave size, QRS complex width, QT interval, QRS voltage, mean QRS electrical axis, $\mathrm{R}$ wave progression in chest leads, Abnormal Q wave, ST segments, T wave, U wave.

Statistical analysis of data: The collected data was organized, tabulated and statistically analyzed using statistical package of social sciences [SPSS] for windows, version 16. Categorical variables were represented as relative frequencies and percent distribution and for comparison between groups; the Chi square test $\left[\mathrm{X}^{2}\right]$ was used. Continuous, quantitative data were represented as arithmetic mean and standard deviation, and for comparison between two means, the independent samples student $[\mathrm{t}]$ test was used. For interpretation of results, the $p$ value $\leq 0.05$ was considered significant.

\section{RESULTS}

As regard environmental factors, there was significant increase of known risk factors in study group, when compared to control group (table 1). As regard to age of studied subjects, it ranged from 30 to 50 years with a mean of $38.52 \pm 5.18$ years and there was non significant decrease of age of cases when compared to controls [38.41 \pm 5.54 vs $38.63 \pm 4.80$ years respectively]. As regard marital state, $84.6 \%$ of studied subjects were married, $3.3 \%$ were single, $6.7 \%$ were divorced and $5.4 \%$ were widows and there was non significant difference between cases and controls. In study group, $81.7 \%$ were 
married, $4.2 \%$ were single, $8.3 \%$ were divorced and $5.8 \%$ were widows. Regarding smoking habit, $40 \%$ of all studied subjects were smokers, with significant increase in study group when compared to control group [54.2\% vs $25.8 \%$ respectively]. alcohol drinking was reported in $3.3 \%$ of all studied subjects, with no significant difference between cases and controls [it was $5.0 \%$ in cases compared to $1.7 \%$ of controls]. Regarding BMI in studied cases, it ranged from 22.39 to $38.74 \mathrm{~kg} / \mathrm{m} 2$ with a mean of $29.06 \pm 2.73$ and there was non significant increase in study group when compared to control group [29.31 \pm 3.24 vs $28.81 \pm 2.08$ respectively] (table 2). As regard to past history, there was positive past history of hypertension in $10.8 \%$ of all studied subjects, with significant increase in study when compared to controls [17.5\% vs $4.2 \%$ ]. In addition, there was positive past history of both diabetes and atherosclerosis in $7.1 \%$ of all studied subjects and there was significant increase in cases when compared to controls [10.8\% vs $3.3 \%$ respectively]. On the other hand, no positive past history was reported for cerebrovascular stroke, or positive family history of similar diseases (table 2).

Regarding duration of work in studied subjects, it ranged from 6 to 22 years with a mean of $10.0 \pm 3.38$ and there was non significant increase of work duration in study group when compared to control group [10.35 $\pm 4.11 \mathrm{vs}$ $9.66 \pm 2.40$ years respectively]. Job type was spinning was reported in $16.7 \%$, weaving in $17.5 \%$, bleaching in $15.8 \%$, printing in $16.7 \%$, dye sector in $21.7 \%$ and knitting in $11.7 \%$ (Table 3). Regarding blood pressure, there was significant increase of systolic, diastolic and mean blood pressure in study group when compared to control group. In addition, there was significant increase of HR in study group in comparison to control group. Random blood 
sugar ranged from 125 to 270 with a mean of $144.73 \pm 19.61 \mathrm{~g} / \mathrm{dl}$ with a non significant increase in study when compared to control group. On the other hand, there was significant increase of cholesterol, triglycerides, LDL and significant decrease of HDL in study group when compared to control subjects (Table 4).

As regard ECG abnormalities, it was in the form of dysrhythmia in $7.1 \%$, prolonged PR interval in 5.4\%, enlarged $\mathrm{P}$ wave in $7.5 \%$, widened QRS complex in $11.2 \%$, pathological Q wave in 5.4\%, increased QRS amplitude in $3.8 \%$ and depressed ST segment in $10.8 \%$ and there was significant increase of all ECG abnormalities in study group when compared to control group. In study group, dysrhythmia was reported in $13.3 \%$, prolonged PR interval in $10.0 \%$, enlarged $\mathrm{P}$ wave in $12.5 \%$, widened QRS complex in $17.5 \%$, pathological Q wave in 9.2\%, increased QRS amplitude in 6.7\% and depressed ST segment in $18.3 \%$ (table 5).

Table(1): Comparison between cases and controls as regard to environmental risk factors

\begin{tabular}{||l|c|c|c|c|c|c|c|c||}
\hline & \multicolumn{2}{|c|}{ Study[120] } & \multicolumn{2}{c|}{ Control[12] } & \multicolumn{2}{c|}{ Total [120] } & \multicolumn{2}{|c|}{ Statistics } \\
\cline { 2 - 10 } & $\mathbf{n}$ & $\mathbf{\%}$ & $\mathbf{n}$ & $\mathbf{\%}$ & $\mathbf{n}$ & $\mathbf{\%}$ & $\mathbf{X}^{\mathbf{2}}$ & $\mathbf{p}$ \\
\hline \hline $\begin{array}{l}\text { Exposure to } \\
\text { hazardous chemical }\end{array}$ & 78 & $65.0 \%$ & 20 & $16.7 \%$ & 98 & $40.8 \%$ & 58.01 & $<0.001^{*}$ \\
\hline Exposure to noise & 52 & $43.3 \%$ & 25 & $20.8 \%$ & 77 & $32.1 \%$ & 13.94 & $<0.001^{*}$ \\
\hline $\begin{array}{l}\text { Wide temperature } \\
\text { variations }\end{array}$ & 51 & $42.5 \%$ & 20 & $16.7 \%$ & 71 & $29.6 \%$ & 19.22 & $<0.001^{*}$ \\
\hline High humidity & 63 & $52.5 \%$ & 42 & $35.0 \%$ & 105 & $43.8 \%$ & 7.46 & $0.006^{*}$ \\
\hline $\begin{array}{l}\text { Exposure to } \\
\text { electromagnetic } \\
\text { fields }\end{array}$ & 90 & $75.0 \%$ & 56 & $46.7 \%$ & 146 & $60.8 \%$ & 20.22 & $<0.001^{*}$ \\
\hline $\begin{array}{l}\text { Exposure to } \\
\text { vibration }\end{array}$ & 94 & $78.3 \%$ & 63 & $52.5 \%$ & 157 & $65.4 \%$ & 17.69 & $<0.001^{*}$ \\
\hline \hline
\end{tabular}


Table(2): Comparison between cases and controls as regard subject characteristics and past history

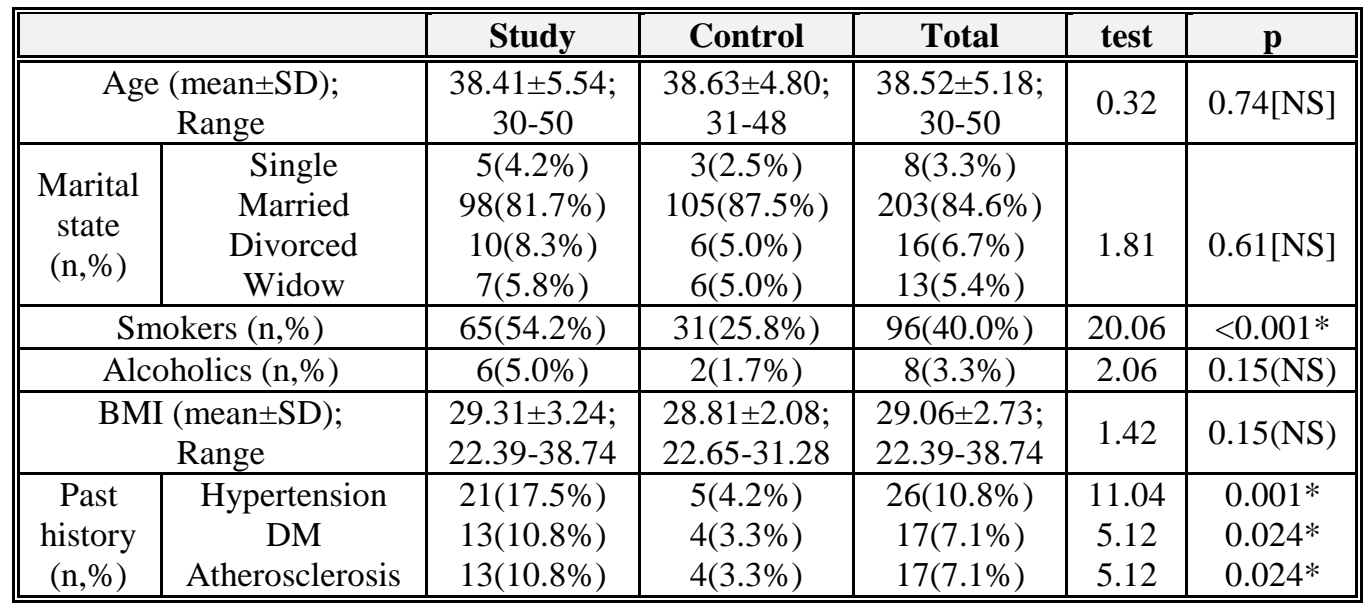

Table (3): work duration and job type in studied subjects

\begin{tabular}{|c|c|c|c|c|c|c|}
\hline & Study & Control & Total & test & $\mathbf{p}$ \\
\hline \multicolumn{2}{|c|}{$\begin{array}{c}\text { Work duration } \\
\text { (mean } \pm \text { SD);Range }\end{array}$} & $\begin{array}{c}10.35 \pm 4.11 \\
6.0-22.0\end{array}$ & $\begin{array}{c}9.66 \pm 2.40 ; \\
6.0-16.0\end{array}$ & $\begin{array}{c}10.0 \pm 3.38 \\
6.0-22.0\end{array}$ & 1.57 & $0.12(\mathrm{NS})$ \\
\hline $\begin{array}{c}\text { Job } \\
\text { type } \\
(\mathrm{n}, \%)\end{array}$ & $\begin{array}{c}\text { Spinning; } \\
\text { Weaving } \\
\text { Bleaching; } \\
\text { Printing } \\
\text { Dye sector; } \\
\text { Knitting }\end{array}$ & $\begin{array}{c}20(16.7 \%) ; \\
21(17.5 \%) \\
19(15.8 \%) ; \\
20(16.7 \%) \\
26(21.7 \%) ; \\
14(11.7 \%)\end{array}$ & & & & \\
\hline
\end{tabular}


J. Environ. Sci.

Institute of Environmental Studies and Research - Ain Shams University

Table (4): Comparison between cases and controls as regard to clinical and laboratory findings

\begin{tabular}{|c|c|c|c|c|c|}
\hline & 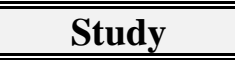 & Control & $\begin{array}{l}\text { Total } \\
\end{array}$ & test & $\mathbf{p}$ \\
\hline $\begin{array}{c}\text { Systolic BP } \\
\text { (mean } \pm \text { SD); } \\
\text { Range }\end{array}$ & $\begin{array}{c}123.42 \pm 17.35 \\
100.0-170.0\end{array}$ & $\begin{array}{c}116.79 \pm 8.06 \\
110.0-150.0\end{array}$ & $\begin{array}{c}120.10 \pm 13.90 \\
100.0-170.0\end{array}$ & 3.79 & $<0.001 *$ \\
\hline $\begin{array}{c}\text { Diastolic BP } \\
\text { (mean } \pm \text { SD); } \\
\text { Range }\end{array}$ & $\begin{array}{c}81.12 \pm 13.10 \\
60.0-115.0\end{array}$ & $\begin{array}{l}76.70 \pm 6.90 \\
70.0-105.0\end{array}$ & $\begin{array}{c}78.91 \pm 10.68 \\
60.0-115.0\end{array}$ & 3.26 & $0.001 *$ \\
\hline $\begin{array}{c}\text { Mean BP } \\
(\text { mean } \pm \text { SD }) \\
\text { Range }\end{array}$ & $\begin{array}{l}95.22 \pm 14.44 \\
73.33 \pm 131.67\end{array}$ & $\begin{array}{l}90.06 \pm 7.25 \\
83.33 \pm 120.0\end{array}$ & $\begin{array}{c}92.64 \pm 11.69 \\
73.33\end{array}$ & 3.49 & $0.001 *$ \\
\hline $\begin{array}{c}\mathrm{HR} \\
\text { (mean } \pm \mathrm{SD}) ; \\
\text { Range }\end{array}$ & $\begin{array}{c}81.30 \pm 5.53 \\
72.0-100.0\end{array}$ & $\begin{array}{c}79.79 \pm 4.50 \\
74.0-87.0\end{array}$ & $\begin{array}{l}80.5 \pm 5.09 \\
72.0-100.0\end{array}$ & 2.32 & $0.021 *$ \\
\hline $\begin{array}{c}\text { Random BS } \\
\text { (mean } \pm \text { SD); } \\
\text { Range }\end{array}$ & $\begin{array}{c}146.39 \pm 25.18 \\
125.0-270.0\end{array}$ & $\begin{array}{c}143.07 \pm 11.51 \\
125.0-200.0\end{array}$ & $\begin{array}{c}144.73 \pm 19.61 \\
125.0-270\end{array}$ & 1.30 & 0.19 (NS) \\
\hline $\begin{array}{c}\text { Cholesterol } \\
\text { (mean } \pm \text { SD); } \\
\text { Range }\end{array}$ & $\begin{array}{c}131.85 \pm 33.57 \\
90.0-230.0\end{array}$ & $\begin{array}{c}113.48 \pm 11.68 \\
90.0-160.0\end{array}$ & $\begin{array}{c}122.66 \pm 26.71 \\
90-230.0\end{array}$ & 5.66 & $<0.001 *$ \\
\hline $\begin{array}{c}\mathrm{TG} \\
(\text { mean } \pm \mathrm{SD}) \\
\text { Range } \\
\end{array}$ & $\begin{array}{c}88.58 \pm 27.30 \\
9.0-140.0\end{array}$ & $\begin{array}{c}76.80 \pm 28.38 \\
9.0-120.0\end{array}$ & $\begin{array}{c}82.69 \pm 28.41 \\
9.0-140.0\end{array}$ & 3.27 & $<0.001^{*}$ \\
\hline $\begin{array}{c}\mathrm{HDL} \\
\text { (mean } \pm \mathrm{SD}) ; \\
\text { Range }\end{array}$ & $\begin{array}{c}45.44 \pm 7.12 \\
30.0-58.0\end{array}$ & $\begin{array}{c}49.23 \pm 5.67 \\
35.0-58.0\end{array}$ & $\begin{array}{c}47.33 \pm 6.70 \\
30.0-58.0\end{array}$ & 4.55 & $<0.001 *$ \\
\hline $\begin{array}{c}\mathrm{LDL} \\
\text { (mean } \pm \mathrm{SD}) \\
\text { Range }\end{array}$ & $\begin{array}{c}102.69 \pm 14.66 \\
78.0-140.0\end{array}$ & $\begin{array}{c}96.89 \pm 12.25 \\
78.0-130.0\end{array}$ & $\begin{array}{c}99.79 \pm 13.79 \\
78.0-140.0\end{array}$ & 3.32 & $0.001 *$ \\
\hline
\end{tabular}


Table (5): Comparison between cases and controls as regard ECG abnormalities

\begin{tabular}{||l|l|l|l|l|l|l|l|l||}
\hline & \multicolumn{2}{l}{$\begin{array}{l}\text { Study } \\
{[\mathbf{1 2 0}]}\end{array}$} & \multicolumn{2}{l|l}{$\begin{array}{l}\text { Control } \\
{[\mathbf{1 2 0}}\end{array}$} & \multicolumn{2}{l|}{$\begin{array}{l}\text { Total } \\
{[\mathbf{1 2 0}}\end{array}$} & \multicolumn{2}{l||}{ Statistics } \\
\cline { 2 - 11 } & $\mathbf{n}$ & $\mathbf{\%}$ & $\mathbf{n}$ & $\mathbf{\%}$ & $\mathbf{n}$ & $\mathbf{\%}$ & $\mathbf{X}^{\mathbf{2}}$ & $\mathbf{p}$ \\
\hline \hline Dysrhythmia & 16 & $13.3 \%$ & 1 & $0.8 \%$ & 17 & $7.1 \%$ & 14.24 & $<0.001^{*}$ \\
\hline Prolonged PR interval & 12 & $10.0 \%$ & 1 & $0.8 \%$ & 13 & $5.4 \%$ & 9.84 & $0.002^{*}$ \\
\hline Enlarged p wave & 15 & $12.5 \%$ & 3 & $2.5 \%$ & 18 & $7.5 \%$ & 8.64 & $0.003^{*}$ \\
\hline Widened QRS complex & 21 & $17.5 \%$ & 6 & $5.0 \%$ & 27 & $11.2 \%$ & 9.39 & $0.002^{*}$ \\
\hline Pathological Q wave & 11 & $9.2 \%$ & 2 & $1.7 \%$ & 13 & $5.4 \%$ & 6.58 & $0.010^{*}$ \\
\hline Increased QRS amplitude & 8 & $6.7 \%$ & 1 & $0.8 \%$ & 9 & $3.8 \%$ & 5.65 & $0.017^{*}$ \\
\hline Depressed ST segment & 22 & $18.3 \%$ & 4 & $3.3 \%$ & 26 & $10.8 \%$ & 13.97 & $<0.001^{*}$ \\
\hline
\end{tabular}

\section{DISCUSSION}

Cotton is one of the oldest and most popular natural raw materials used by man. It is a renewable, biodegradable and biocompatible polymer, which can be used to manufacture a variety of products [Chmielewska and Sartowska, 2012].

Cardiovascular disease [CVD] is the leading cause of morbidity and mortality worldwide.1 Most of CVD is attributable to modifiable risk factors, such as diabetes, hypertension, obesity, dyslipidemia, smoking, dietary factors, psychosocial stressors, alcohol consumption patterns, and physical inactivity, which account for more than $90 \%$ of myocardial infarction [MI] cases and more than $80 \%$ of stroke cases globally [O'Donnell et al., 2010]. Environmental factors, such as particulate air pollution, have also been implicated in the increasing risk of cardiovascular events from short- and long-term exposure [Miller et al., 2007; Brook et al., 2010]. Similar particulate exposures can occur in the workplace, as well as exposures to metals, solvents, and pollutant gases that have also been shown to increase 
J. Environ. Sci.

Institute of Environmental Studies and Research - Ain Shams University

the incidence of CVD [Bhatnagar, 2006; Sjogren et al., 2012]. Many of these exposures can be found in the textile industry, including fiber dusts and endotoxin, a component of gram-negative bacteria. Endotoxin is widespread in the cotton textile industry and in other industrial and agricultural settings, and may trigger or accelerate atherosclerosis [thickening of arterial walls] either by acting as a source of inflammation or other mechanisms [Stoll et al., 2004]

The aim of the present study was to estimate environmental indicators and risk factors for cardiac malfunction. It was carried out on 240 subjects working on textile factories. 120 of them working in textile industry proper. The other 120 subjects were none exposed and assigned as a control group.

As regard environmental factors, there was significant increase of known risk factors in study group, when compared to control group. The job type was spinning was reported in $16.7 \%$, weaving in $17.5 \%$, bleaching in $15.8 \%$, printing in $16.7 \%$, dye sector in $21.7 \%$ and knitting in $11.7 \%$. These results are in agreement with Brook et al. [2010] who reported that, jobs in the cotton SWK and wool SWK sectors commonly include exposure to fiber dusts, considered similar to particulate exposures. Short- and long-term exposures to ambient particulate matter have been shown consistently to increase risk of cardiovascular events in epidemiological studies of community air pollution. Pathogenetic mechanisms are uncertain, but inhaling small particles may induce changes in blood pressure, inflammation, autonomic balance, and blood coagulation [Bhatnagar, 2006]. Increased blood pressure as a pathogenic mechanism was supported in the present study, as it 
was found that, there was significant increase of systolic, diastolic and mean blood pressure in study group when compared to control group. In addition, there was significant increase of HR in study group in comparison to control group.

Workers react with noise by a complex set of bodily responses known as stress, or arousal. Such changes may include increase in blood pressure, change in heart rate, rise in blood cholesterol, or excessive secretion of hormones. Occupational noise in industries has been pointed out as a stressor that could potentially induce hypertension. Fears have arisen about the adverse health effects [e.g. cardiovascular disease] in workers exposed to noise from textile industries [Kalantari, 2006]. Also, endotoxin exposure is widespread in the textile industry, particularly in cotton factories, and may potentially contribute to an inflammatory response. This may contribute to atherosclerosis [Stoll et al., 2004].

In addition, results of the present study are in agreement with Wernli et al. [2006] who reported that, prevalent exposures in the synthetic sector were reportedly synthetic fiber dusts, solvents, resins and dyes. Similarly, in the bleaching/dyeing/printing sectors a wide variety of expected chemicals include bleaching agents, solvents, acids, bases, caustics, dye chemicals, inks, and resins. In addition, in agreement with results of the present work, studies on noise exposure indicate elevations in blood pressure which could contribute to CVD [Price, 2004]. 
Also, results of the present study are comparable to that reported by Tekriwal and Parmar [2012] who reported that, an important extra auditory effect of noise is on blood pressure. The proposed cause of hypertension is stress response. Stress due to noise causes release of adrenocortical hormones which eventually leads to high blood pressure.

As regard to age of studied subjects, it ranged from 30 to 50 years with a mean of $38.52 \pm 5.18$ years and there was non significant decrease of age of cases when compared to controls $[38.41 \pm 5.54$ vs $38.63 \pm 4.80$ years respectively]. Comparable results were reported by Jahanbani [2003] who reported that, in their study, 1070 men aged $18-69$ years [mean $=31.8$ years] were included. In addition, Bayil et al. [2008] reported that, the age of cases was $31.75 \pm 2.12$ compared to $31.35 \pm 3.12$ in controls with no significant difference. Finally, results of the present study are comparable to those reported by Shousha et al. [2008] who reported that, there is no significant difference between the two groups [cases and controls; exposed and nonexposed to cotton mill] according to their age.

Regarding smoking habit, $40 \%$ of all studied subjects were smokers, with significant increase in study group when compared to control group [54.2\% vs $25.8 \%$ respectively]. In contradiction to results of the present study Bayil et al. [2008] reported that, there was no significant difference between cases and controls as regard to smoking habit, although the percentage is higher than that the present study. The possible explanation for this contradiction may be attributed to small number of cases included in their study [20 cases in each group], and different inclusion criteria. On the other hand, it was 
demonstrated that smokers were at increased risk of myocardial infarction or sudden death. Moreover, risk was related to the number of cigarettes smoked each day [O'Donnell and Elosua, 2008]. These results were confirmed by other epidemiological studies [Lakier, 1992], placing smoking as a high priority on the preventive agenda.

Regarding duration of work in studied subjects, it ranged from 6 to 22 years with a mean of $10.0 \pm 3.38$ and there was non significant increase of work duration in study group when compared to control group [10.35 \pm 4.11 vs $9.66 \pm 2.40$ years respectively]. Comparable results are reported by Bayil et al. [2008] reported that, the mean duration of work in study group was $8.27 \pm 3.87$ years.

Regarding BMI in studied cases, it ranged from 22.39 to $38.74 \mathrm{~kg} / \mathrm{m}^{2}$ with a mean of $29.06 \pm 2.73$ and there was non significant increase in study group when compared to control group [29.31 \pm 3.24 vs $28.81 \pm 2.08$ respectively]. These results are in agreement with previous studies, where it had been reported that, obesity is a chronic metabolic disorder associated with numerous co-morbidities such as CHD, CVD [Wilson et al., 2002], type 2 diabetes [Eckel et al., 2006], hypertension, certain cancers, and sleep apnea. In addition to alterations in metabolic profile, various adaptations in cardiac structure and function occur as excess adipose tissue accumulates [Poirier et al., 2006]. Similar to data observed with LDL-C(low density lipoprotein cholesterol) and supporting the idea that the progression of athero-sclerosis should be viewed as a continuous process beginning early in life, a more recent study reported that higher BMI during childhood is associated with an increased risk of CHD in adulthood. This association seems to be stronger in 
boys than in girls and increases with the age of the child in both sexes [Baker et al., 2007].

Regarding blood pressure, there was significant increase of systolic, diastolic and mean blood pressure in study group when compared to control group. In addition, there was significant increase of HR in study group in comparison to control group. These results agreed with van den Hoogen et al. [2000] who demonstrated that systolic and diastolic blood pressure has a continuous, independent, graded, and positive association with cardiovascular outcomes. It had been further reported that, even high-normal blood pressure values are associated with an increased risk of cardiovascular disease [Vasan et al., 2001]. In addition, it had been reported that, for individuals aged 40 to 70 years, each increment of $20 \mathrm{mmHg}$ in systolic blood pressure or $10 \mathrm{mmHg}$ in diastolic blood pressure doubles the risk of CVD across the entire range of blood pressure from 115/75 to 185/115 $\mathrm{mm} \mathrm{Hg}$ [Lewington et al., 2002].

Regarding random blood sugar, it ranged from 125 to 270 with a mean of $144.73 \pm 19.61 \mathrm{~g} / \mathrm{dl}$ with a non significant increase in study when compared to control group. These results are in agreement with previous studies in literature, where it was reported that, diabetes is associated with a 2- to 3-fold increase in the likelihood of developing CVD, glucose intolerance is also associated with a 1.5-fold increase in the risk of developing cardiovascular disease [Fox et al., 2004]. Moreover, diabetes is also associated with a higher probability of presenting with hypertriglyceridemia, low HDL-C, high blood pressure, and obesity, which usually precede the onset of diabetes. Insulin resistance has been suggested to be a common mechanism for these risk 
factors, the association of which is referred to as the metabolic syndrome [Grundy et al., 2005], but there are still some doubts about the common mechanism and the added value of this diagnosis instead of the individual diagnosis of each component [Kahn et al., 2005].

In the present work, there was significant increase of cholesterol, triglycerides, LDL and significant decrease of HDL in study group when compared to control subjects. These results are in agreement with several studies in literature, where these studies showing a strong relation between serum total cholesterol and cardiovascular risk [Anderson et al., 1987]. In light of these studies, clinicians and epidemiologists agreed that total plasma cholesterol was a useful marker for predicting CVD. These findings were confirmed when low density lipoprotein cholesterol [LDL-C], the principal lipoprotein transporting cholesterol in the blood was also directly associated with CVD. Moreover, LDL cholesterol levels in young adulthood predict development of CVD later in life, supporting the idea that the relationship between LDL-C and development of CVD should be viewed as a continuous process beginning early in life [Stamler et al., 2000]. Meanwhile, other studies were beginning to highlight the fact that individuals with high HDL levels were less likely to present CHD than individuals with low HDL levels [Law et al., 1994].

As regard ECG abnormalities, it was in the form of dysrhythmia in 7.1\%, prolonged $\mathrm{PR}$ interval in 5.4\%, enlarged $\mathrm{P}$ wave in $7.5 \%$, widened QRS complex in $11.2 \%$, pathological Q wave in $5.4 \%$, increased QRS amplitude in $3.8 \%$ and depressed ST segment in $10.8 \%$ and there was significant increase of all ECG abnormalities in study group when compared to control group. In 
study group, dysrhythmia was reported in $13.3 \%$, prolonged PR interval in $10.0 \%$, enlarged $\mathrm{P}$ wave in $12.5 \%$, widened $\mathrm{QRS}$ complex in $17.5 \%$, pathological Q wave in 9.2\%, increased QRS amplitude in 6.7\% and depressed ST segment in $18.3 \%$. These results are in agreement with Tuchsen et al. [1992] who reported increased hospitalization for ischemic heart disease was seen among workers self employed in textile industry.

Kamal et al. [1991] were the first to demonstrate more convincing results in ECG pathologic changes in the exposed workers. However, they were unable to relate the values of ECG components to the duration of the exposure to the chemical as well. Kuo et al. [1997] were also unable to show the duration of employment is an important factor.

In short, results of the present study revealed an association between environmental risk factors and development of cardio-vascular disease; and it can be explained by that: environmental risk especially noise and temperature variations leads to increased traditional risk factors of CVD and subsequently development of the disease.

\section{REFERENCES}

Anderson KM, Castelli WP, Levy D.(1987): Cholesterol and mortality: 30 years of follow-up from the Framingham Study. JAMA; 257:2176-80.

Baker JL, Olsen LW, Sørensen TI.(2007): Childhood body-mass index and the risk of coronary heart disease in adulthood. NEJM;357:232937.

Bayil S, Cicek H, Cimencl IG. (2008): How volatile organic compounds affect free radical and antioxidant enzyme activity in textile workers. Arch Hig Rada Toksikol; 59:283-287 
Bhatnagar A.(2006): Environmental cardiology: Studying mechanistic links between pollution and heart disease. Circ Res; 99:692-705.

Brook RD, Rajagopalan S, Pope CA III, Brook JR, Whitsel L, Kaufman JD. (2010): Particulate matter air pollution and cardiovascular disease: An update to the scientific statement from the American Heart Association. Circulation; 121:2331-2378.

Chmielewska D,Sartowska B.(2012): Radiation synthesis of silver nanostructures in cotton matrix. Radiation Physics and Chemistry; 81: $1244-1248$

Eckel RH, Kahn R, Robertson RM, Rizza RA.(2006): Preventing cardiovascular disease and diabetes: a call to action from the American Diabetes Association and the American Heart Association. Diabetes Care;29:1697-9.

Fox C, Coady S, Sorlie P, Levy D, D'Agostino RB Jr(.2004): Trends in cardiovascular complications of diabetes. JAMA;292:2495-9.

Grundy SM, Cleeman JI, Daniels SR, Donato KA.(2005): Diagnosis and management of the metabolic syndrome: an American Heart Association/National Heart, Lung, and Blood Institute Scientific Statement. Circulation;112:2735-52.

Harding AH, Darnton A, Osman J.(2012): Cardiovascular disease mortality among British asbestos workers [1971-2005]. Occup Environ Med; 69: 417-21.

Jahanbani J. (2003): Prevalence of oral leukoplakia and lichen planus in 1167 Iranian textile workers. Oral Diseases; 9, 302-304

Kahn R, Buse J, Ferrannini E, Stern M. (2005):The metabolic syndrome: time for a critical appraisal: joint statement from the American Diabetes Association and the European Association for the Study of Diabetes. Diabetes Care; 28:2289-304.

Kamal AA, Ahmed A, Saied K, Metwally M. (1991): Quantitative evaluation of ECG components of workers exposed to carbon disulfide. Environ Health Perspect.;90:301-304. 
Kristensen TS. (1989): Cardiovascular diseases and the work environment. A critical review of the epidemio-logic literature on chemical factors. Scand J Work Environ Health ;15(4):245-64.

Kuo HW, Lai JS, Lin M, Su ES. (1997): Effects of exposure to carbon disulfide [CS2] on electrocardiographic features of ischemic heart disease among viscose rayon factory workers. Int Arch Occup Environ Health.;70:61- 66.

Lakier JB. (1992): Smoking and cardiovascular disease. Am J Med; 93 Suppl 1A: A1-8.

Law MR, Wald NJ, Thompson SG. (1994): By how much and how quickly does reduction in serum cholesterol concentration lower risk of ischemic heart disease. BMJ; 308:367-72.

Lewington S, Clarke R, Qizilbash N, Peto R, Collins R.(2002): Age specific relevance of usual blood pressure to vascular mortality. Lancet;360:1903-13.

Metcalf, Allan A. (1999): The World in So Many Words. Houghton Mifflin; p. 123.

Miller KA, Siscovick DS,(2007): Sheppard L, Kaufman JD. Long-term exposure to air pollution and incidence of cardiovascular events in women. N Engl J Med; 356:447-458.

Molyneux MK, Tombleson JB. (1963): An epidemiological study of respiratory symptoms in Lancashire mills, $-66 . \mathrm{Br} \mathrm{J}$ Ind Med. $1970 \mathrm{Jul} ; 27(3): 225-34$.

O’Donnell CJ, Elosua R. (2008): Cardiovascular Risk Factors. Insights from Framingham Heart Study. Rev Esp Cardiol; 61[3]:299-310

O’Donnell MJ, Xavier D, Liu L. (2010): Risk factors for ischaemic and intracerebral haemorrhagic stroke in 22 countries [the INTERSTROKE study]: a case-control study. Lancet; 376:11223.

Poirier P, Giles TD, Bray GA, Hong Y, Stern JS, Pi-Sunyer FX.(2006): Obesity and cardiovascular disease: Pathophysiology, evaluation, and effect of Council on Nutrition, Physical Activity, and 
Metabolism Statement on Obesity and Heart Disease From the Obesity Committee of the Weight Loss: An update of the 1997 American Heart Association Scientific. Circulation;113;898-918.

Price AE. Heart disease and work. Heart (2004): 90:1077-1084.

Shousha WG, Hussein AS, Sharada HA. (2008): Biomarkers for rheumatoid arthritis in textile workers and the role of sex hormones. The Egyptian Journal of Biochemistry \& Molecular Biology; 26[2]175-188.

Sjogren B, Lonn M, Feychting M, Nise G, Plato N, Gustavsson P. (2012): Occupational exposure to particles and incidence of stroke. Scand J Work Environ Health; In Press.

Stamler J, Daviglus ML, Garside DB, Dyer AR, Greenland P, Neaton JD. (2000): Relationship of baseline serum cholesterol levels in 3 large cohorts of younger men to long-term coronary, cardiovascular, and all-cause mortality and to longevity. JAMA;284:311-8.

Stoll LL, Denning GM, Weintraub NL. (2004): Potential role of endotoxin as a proinflammatory mediator of atherosclerosis. Arterioscler Thromb Vascular Biol; 24:2227-2236.

Tekriwal R, Parmar DM. (2012): Extra Auditory Effect of Noise - A Study on Textile Workers of Surat City. National Journal of Physiology, Pharmacy \& Pharmacology ,, Vol 2 | Issue 1 | 45 - 51

Tuchsen F, Bach E, Marmot M. (1992): Occupation and hospitalization with ischaemic heart diseases: A new nationwide surveillance system based on hospital admissions. Int J Epidemiol; 21:450-4459.

van den Hoogen PCW, Feskens EJM, Kromhout D. (2000): The relation between blood pressure and mortality due to coronary heart disease among men in different parts of the World. N Engl J Med; 342:1-8.

Vasan RS, Larson MG, Leip EP, Evans JC, O’Donnell CJ, Kannel WB.(2001): Impact of high-normal blood pressure on the risk of cardiovascular disease. N Engl J Med;345:1291-7. 
Wernli KJ, Astrakianakis G, Camp JE, Ray RM, Seixas NS.(2006): Development of a job exposure matrix [JEM] for the textile industry in Shanghai, China. J Occup Environ Hyg; 3:521-529.

Wilson PW, d'Agostino RB, Sullivan L, Parise H, Kannel WB. (2002): Overweight and obesity as determinants of cardiovascular risk: the Framingham experience. Arch Intern Med;162: 1867-72.

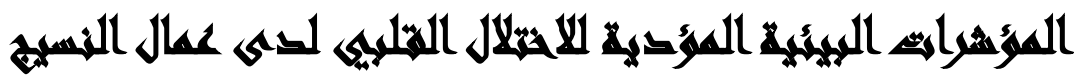

\section{$[\vee]$}

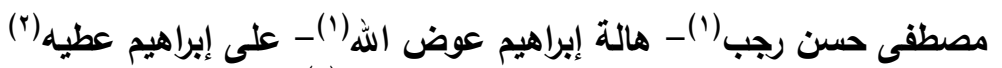

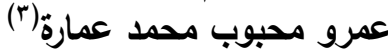

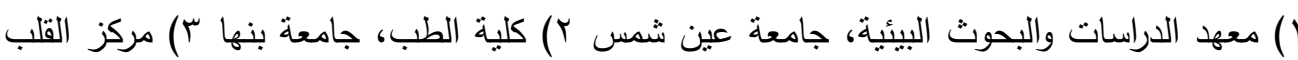
بالمحلة، وزارة الصحة والسكان

\section{المهتخلصى}

صممت الدراسة الحالية بهدف تحديد العوامل البيئية وعوامل الخطورة لأمراض القلب المختلفة

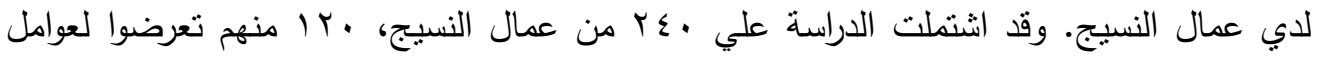

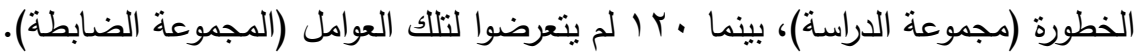
وقد أسفرت نتائج الدراسة عن الآتي: وجدت زيادة بعتد بها إحصائيا في نسبة عوامل الخطورة البيئية

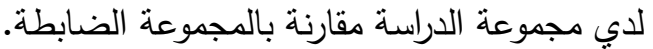

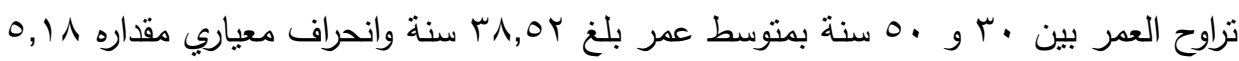

سنة ولم توجد فروق ذات دلالة إحصائية بين مجموعة الدراسة والمجموعة الضابطة المانة

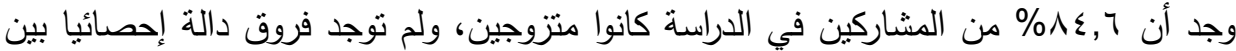
مجموعة الدراسة والمجموعة الضابطة. وجد أن · ؛ \% من المشاركين في الدراسة كانوا من المدخنين، مع وجود زيادة بعتد بها إحصائيا في عدد المدخنين في مجموعة الدراسة مقارنة بالمجموعة الضانة الضابطة.

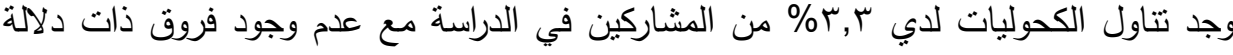
إحصائية بين مجموعتي الدراسة.

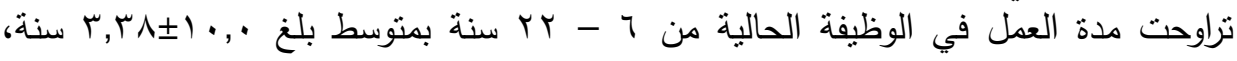
ووجدت زيادة غير دالة إحصائيا لدي مجموعة الدراسة مقارنة بالمجموعة الضابطة. 


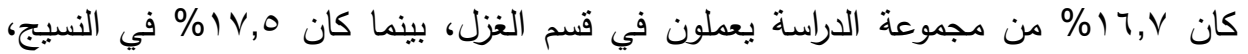

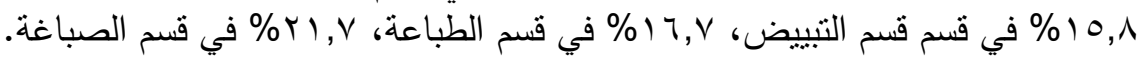

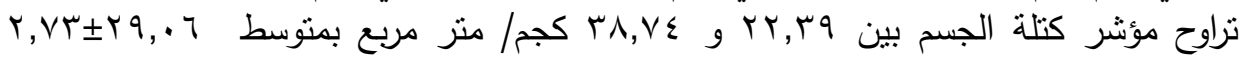

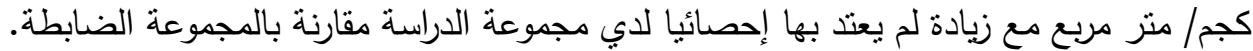

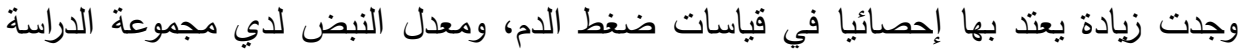

مقارنة بالمجموعة الضابطة.

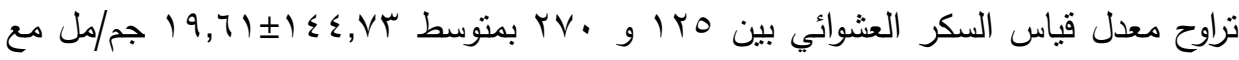
زيادة لا يعتد بها إحصائيا لدي مجموعة الدراسة مقارنة باليكرة بالمجموعة الضابطة.

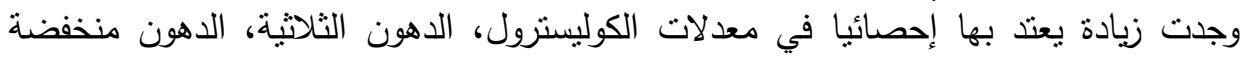

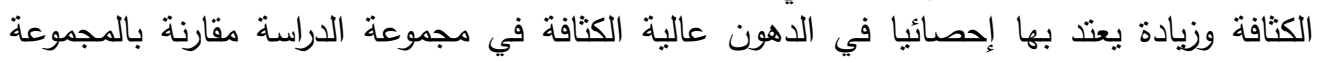
الضابطة.

وجدت زيادة يعتد بها إحصائيا في الاختلالات القلبية علي رسام القلب الكهربائي لدي مجموعة الدراسة مقارنة بالمجموعة الضابطة.

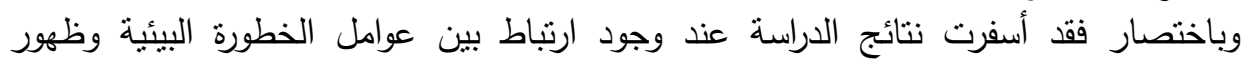

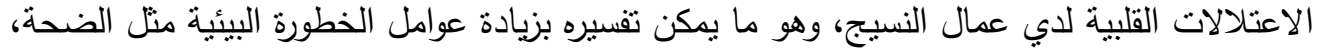

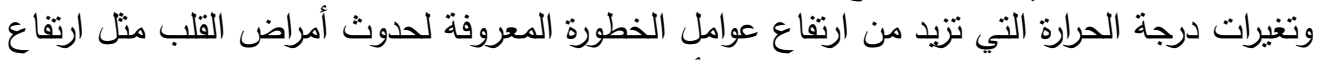

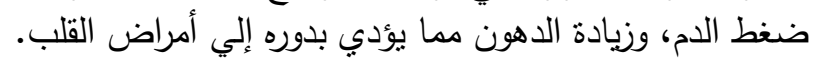

